\title{
KEKHASAN PEMBENTUKAN KATA DALAM \\ CERPEN JODOH KARYA A. A. NAVIS \\ (The Uniqueness of Word-Formation in the Short Story Jodoh by A.A. Navis)
}

\author{
Murmahyati \& Amriani H. \\ Balai Bahasa Sulawesi Selatan \\ Jalan Sultan Alauddin Km 7 Tala Salapang, Makassar, Indonesia \\ Telepon (0411) 882401 \\ Pos-el: atimurmahyati@yahoo.com \\ amrianihappe25@gmail.com \\ (Naskah Diterima Tanggal: 15 Oktober 2019; Direvisi Akhir Tanggal: 25 November 2019; \\ Disetujui Tanggal: 25 November 2019)
}

\begin{abstract}
This research aims to describe the uniqueness of word-formation used in the short story Jodoh by A. A. Navis, in particular, the absorption of affixes and utilization of certain affixes. The method used is a descriptive qualitative with a stylistic approach. The data used in this research are short story Jodoh which is, contained in a collection of short story Jodoh by A. A. Navis published in 1999 by Gramedia. The data collected by library study and analyzed by a descriptive qualitative method. The results showed that many aspects of wordformation use the absorption of affixes (meng, ber, -an, and-kan), absorption of reduplication words, utilization of affixes (se, meng-i (-kan), di-i, and ter-), and the use of basic forms of the Minangkabau language.
\end{abstract}

Keywords: short story; word-formation; utilization of affix; absorption of affix

\begin{abstract}
Abstrak
Penelitian ini bertujuan untuk mendeskripsikan kekhasan pembentukan kata yang digunakan dalam cerpen Jodoh karya A. A. Navis, khususnya pelesapan afiks dan pemanfaatan afiks tertentu. Metode yang digunakan adalah metode deskriptif kualitatif dengan pendekatan stilistika. Data yang digunakan dalam penelitian ini adalah cerpen Jodoh yang dimuat dalam kumpulan cerpen Jodoh karya A. A. Navis yang diterbitkan tahun 1999 oleh Gramedia. Teknik pengumpulan data melalui studi pustaka dan dianalisis dengan metode deskriptif kualitatif. Hasil penelitian menunjukkan bahwa aspek pembentukan kata banyak menggunakan bentuk pelesapan afiks (meng-, ber-, -an, dan-kan), pelesapan bentuk ulang, pemanfaatan afiks (se-, meng-i (-kan), di-i, dan ter-), dan pemanfaatan bentuk dasar bahasa Minangkabau.
\end{abstract}

Kata kunci: cerpen; pembentukan kata; pemanfaatan afiks; pelesapan afiks

\section{PENDAHULUAN}

Bahasa sastra adalah bahasa yang khas. Setiap pengarang memiliki cara yang berbedabeda dalam menghasilkan suatu karya sastra. Hal ini disebabkan adanya keanekaragaman dan gaya berbahasa setiap penulis. Untuk mengetahui kekhasan setiap penulis atau pengarang dalam karyanya, peneliti perlu melakukan kajian dalam hal penggunaan bahasa oleh setiap penulis atau pengarang dalam karya-karyanya. Pengkajian mengenai kekhasan pemakaian bahasa dalam suatu karya sastra dikaji dengan pendekatan stilistika. Objek kajian stilistika pada umumnya bertumpu pada bentuk cara pemaparan gagasan, peristiwa, atau suasana tertentu pada sebuah karya sastra dengan mengkaji potensi-potensi bahasa yang dieksploitasi pengarang untuk tujuan tertentu. Berdasarkan hal tersebut, dapat dianggap bahwa keunikan bentuk kata sebagai wujud pengeksploitasian potensi-potensi bahasa yang merupakan kesengajaan atau intensi pengarang dalam proses kreatifnya.

Berdasarkan sudut pandang tersebut, keunikan sebagai suatu wujud pengeksplotasian potensi-potensi bahasa oleh pengarang sebenarnya merupakan suatu kesengajaan atau intensi pengarang dalam proses kreatifnya. Sehubungan dengan dasar pemikiran yang telah 
dinyatakan di atas, pada kesempatan ini dikaji salah satu keunikan pembentukan kata dalam cerpen Jodoh karya A.A. Navis.

Cerpen adalah suatu cerita tentang sebagian kecil dan kehidupan dengan tokohtokoh yang terbatas jumlahnya dan dengan perkembangan cerita yang berpusat pada satu aspek dan seluruh aspek lainnya dalam kehidupan (Sayekti, 1995). (A Zaidan, 1994) menulis bahwa cerita pendek adalah kisahan yang memberi kesan tunggal yang dominan tentang satu tokoh dalam satu latar dan satu situasi dramatik.

Bahasa cerpen adalah bahasa yang khas, bahasa yang telah dilentur-lenturkan pengarang dan kadang-kadang dengan sengaja dibuat pelanggaran-pelanggaran terhadap kaidah bahasa sehingga mencapai kesan keindahan dan kehalusan rasa (Wellek dan Warren, 2013). Dalam cerpen pengarang menggunakan katakata yang khusus dan susunan kalimat yang khusus menyatakan perasaan dan pikiran yang khusus serta untuk meninggalkan kesan sensitivitas yang khusus pula (Semi, 1993). Berdasarkan gambaran tentang telaah stilistika terhadap karya sastra pada uraian di atas, penelitian ini mengkaji kekhasan pembentukan kata dalam cerpen Jodoh karya A. A. Navis.

Kajian ini dilakukan dengan harapan dapat mengungkapkan hal-hal yang membantu pembaca dalam menangkap dan menafsirkan makna cerpen Jodoh karya A. A. Navis. Selain itu, pengkajian stilistika juga membantu pembaca memahami cara pengarang memanfaatkan potensi-potensi bahasa untuk mencapai efek tertentu. Bahasa yang digunakan Navis dalam cerpen Jodoh ini memiliki karakteristik tersendiri dan sangat berbeda dengan bahasa sehari-hari.

Dalam cerpen Jodoh karya A. A. Navis, terdapat kekhasan dalam pembentukan kata. Oleh karena itu, penulis tertarik untuk melihat hal tersebut. Tujuan penelitian ini adalah menelusuri kekhasan pembentukan kata yang digunakan oleh A. A. Navis dalam cerpennya yang berjudul Jodoh.

\section{KERANGKA TEORI}

Medium utama karya sastra adalah bahasa. Karya sastra bukanlah bahasa formal, bahasa harus dipahami sebagai entitas yang telah memiliki hakikat tersendiri. Pada umumnya kreativitas dan imajinasi, sistem konvensi, dan hubungannya dengan struktur sosiokultural secara keseluruhan dianggap sebagai ciriciri utama dalam rangka membedakan antara puitika bahasa dan sastra. Analisis stilistika adalah analisis bahasa itu sendiri dengan mempertimbangkan keterkaitannya dengan konvensi sastra dan budaya (Ratna, 2016).

Hal mendasar yang perlu dihayati dan dipahami bersama adalah bahwa karya sastra sebagai wacana sastra dan susastra termasuk karya seni yang bermediumkan bahasa. Tanpa adanya bahasa manusia yang alami tak dapat dibayangkan adanya sebuah karya sastra. Karya sastra tak dapat dilepaskan dari bahasa manusia yang bersifat alami. Setiap bahasa memiliki piranti-piranti, memiliki unsur-unsur (bunyi bahasa, suku kata, morfem, kata, frase, kalimat, dan wacana), memiliki keseluruhan kaidah atau sistem yang bersifat mengatur bagaimana satuan atau unsur itu berkombinasi satu sama lain, dan memiliki pola-pola konstruksi atau bentukan. Dengan perkataan lain, setiap bahasa memiliki kaidah, unsur, dan potensi-potensi (Subroto, 1999)

Secara umum, gaya atau style adalah cara mengungkapkan diri sendiri, entah melalui bahasa, tingkah laku, dan berpakaian sehingga dikenal gaya berpakaian, gaya menulis, dan gaya berjalan. Dengan demikian dapat dikatakan bahwa gaya adalah cara yang khas dipakai seseorang untuk mengungkapkan diri (gaya pribadi) (Keraf, 1990).

Stilistika sering dikaitkan dengan bahasa sastra, meskipun Chapman menyatakan bahwa kajian ini dapat ditujukan terhadap berbagai ragam penggunaan bahasa (Nurgiyantoro, 2014). Lebih lanjut Chapman menyatakan bahwa analisis stilistika dimaksudkan untuk menentukan seberapa jauh penyimpangan bahasa yang digunakan pengarang serta 
bagaimana pengarang mempergunakan tandatanda linguistik untuk memperoleh efek estetis atau puitis (Nurgiyantoro, 2014). Dengan demikian, stilistika tidak dapat diterapkan dengan baik tanpa dasar linguistik yang kuat sebab salah satu perhatian utamanya adalah kontras sistem bahasa sastra dengan bahasa pada zamannya (Wellek dan Warren, 2013).

Menurut (Sudjiman, 1993), stilistika adalah suatu ilmu yang digunakan untuk mengkaji cara sastrawan memanipulasi, dengan arti memanfaatkan unsur dan kaidah yang terdapat dalam bahasa dan efek yang ditimbulkan. Stilistika juga meneliti ciri khas penggunaan bahasa dalam wacana sastra, ciriciri yang membedakan atau mempertentangkan dengan wacana nonsastra, meneliti deviasi terhadap tata bahasa sebagai sarana literer. Jadi. stilistika meneliti fungsi puitik suatu bahasa. Pendekatan stilistika berkaitan erat dengan berbagai cabang dan tataran linguistik. Karena itu, kajian stilistika dapat bergerak pada tataran fonologis, morfologis, sintaksis, atau semantik (Sudjiman, 1993).

Dalam kajian stilistika, pemanfaatan dimaksudkan dengan memanfaatkan potensipotensi dan kemampuan bahasa secara inovatifkreatif. Pemanfaatan dapat diartikan dengan memainkan sarana bahasa secara inovatif, memanfaatkan kemungkinan potensi bahasa yang tersedia, memanipulasi kaidah yang umum berlaku, tetapi masih dalam batas-batas konvensi (Sudjiman, 1993)

Merujuk beberapa pendapat para pakar menyatakan kajian stilistika pada sebuah karya sastra dapat dilakukan dengan mengkaji bentuk atau unsur-unsur yang dibentuk dan tandatanda linguistik yang digunakan dalam struktur lahir karya sastra tersebut. Bentuk atau unsurunsur yang dimaksud atau unsur-unsur stilistika sebagai tanda-tanda linguistik dapat berupa fonem, diksi, kalimat, dan wacana bahasa (AlMa'ruf \& Imron, 2012)

Sejalan dengan hal tersebut, (Aminuddin, 1997) mengatakan bahwa style ialah cara penggunaan sistem tanda yang mengandung ide, gagasan, dan nilai keindahan tertentu. Dalam arti yang umum, menurut Aminuddin, gaya juga dapat dipahami sebagai cara yang digunakan penutur dalam memaparkan gagasannya sejalan dengan motif dan tujuan yang ingin dicapai.

Berbicara tentang penggunaan bentuk kata dalam sebuah karya sastra termasuk dalam wilayah kajian stilistika. Pusat perhatian stilistika adalah style, cara yang digunakan seseorang pembicara atau penulis untuk menyatakan maksudnya dengan menggunakan bahasa sebagai sarana.

Unsur bentuk adalah yang pertama dijumpai pembaca ketika berhadapan dengan sebuah karya sastra. Dapat dikatakan bahwa unsur bentuk yang paling utama adalah bahasa. Unsur bentuk yang lain seperti penggunaan simbolisme atau permainan makna yang lain juga hanya dapat dikenali lewat bahasa.

Dalam stilistika, pemanfaatan bentuk kata seperti itu tidak terjadi secara acak dalam karya sastra (cerpen) dan tidak berdiri sendiri, tetapi berpola dengan gejala linguistik. Salah satu tataran kajian stilistika adalah morfologi yang dapat menganalisis pemanfaatan bentuk kata dalam sebuah karya sastra. Pemanfaatan bentuk kata sendiri mempunyai dua aspek, yaitu aspek bentuk dan aspek makna. Aspek bentuk merujuk pada wujud visual suatu bahasa, sementara aspek makna merujuk pada pengertian yang ditimbulkan oleh wujud visual bahasa itu (Mustakim, 1994). Jadi bentuk kata adalah wujud visual kata yang digunakan dalam sutau bahasa serta proses pembentukannya.

Dalam bahasa Indonesia, proses pembentukan kata dapat dilakukan dengan pengimbuhan. Pengimbuhan adalah proses pembentukan kata dengan menambahkan imbuhan pada kata dasar atau bentuk dasar tertentu. Bentuk imbuhan itu meliputi prefiks, sufiks, infiks, dan konfiks. Jadi, bentuk kata dalam bahasa Indonesia merupakan satuan yang terdiri atas satu morfem atau lebih. Misalnya, kata berhak dilihat dari bentuk katanya terdiri atas dua satuan minimal, yaitu ber- dan hak; 
satuan minimal gramatikal dinamai morfem (Verhaar, 1996). Pembicaraan tentang bentuk kata termasuk persoalan morfologis, yaitu bagaimana kata dibentuk dari morfem-morfem (Badudu, 1982)

Bahasa yang digunakan Navis pada dasarnya adalah bahasa yang merefleksikan penggunaan bahasa sehari-hari. Pada umumnya gaya bahasa Navis dalam cerpen-cerpennya berangkat dari empat aspek, yaitu pilihan kata atau diksi, pembentukan kata, struktur kalimat, dan gaya bahasa. Keempat hal inilah yang merupakan kekhasan A.A.Navis yang membedakan dari bahasa pengarang lain.

Berdasarkan empat aspek kebahasaan di atas, penelitian ini hanya mengkaji aspek pembentukan kata sebagai ciri khas A. A. Navis. Bentuk kata di sini dititikberatkan pada pemerian bentuk-bentuk kata tertentu seperti pelesapan afiks dan pemanfaatan afiks tertentu.

\section{METODE}

Metode yang digunakan dalam penelitian ini adalah metode deskriptif kualitatif yang bertujuan untuk mendeskripsikan secara sistematis dan akurat fakta-fakta kebahasaan yang tampak, khususnya kekhasan penggunaan kata A. A. Navis dalam cerpennya yang berjudul Jodoh. Penelitian kualitatif dilakukan dengan tidak mengutamakan angka-angka, tetapi menggunakan kedalaman penghayatan terhadap interaksi antarkonsep yang sedang dikaji secara empiris (Endraswara, 2011).

\section{PEMBAHASAN}

\section{Pemanfaatan Bentuk Kata}

Kehadiran afiks dalam suatu kata sangat penting karena dapat memberikan efek struktur dan efek semantis. Dalam cerpen Jodoh Navis banyak melesapkan baik afiks maupun sufiks.

\section{Pelesapan Prefiks meng-}

Dalam cerpen Jodoh ditemukan pelesapan prefik meng- pada kata-kata tertentu. Ada tiga bentuk pelesapan prefiks meng-yang ditemukan yaitu (a) pelesapan prefiks meng- dari bentuk dasar menjadi $D$, (b) penyederhanaan afiks meng- $i$ menjadi $D-i$, dan (c) penyederhanaan afiks meng-kan menjadi D-kan.

\section{a. Pelesapan Prefiks meng- dari Bentuk Dasar}

Penggunaan kata-kata tanpa afiks sangat tinggi frekuensinya. Kata-kata tanpa afiks tersebut merupakan kata yang sengaja dilesapkan dari bentuk dasar. Kata hirau yang lazim digunakan dengan afiks, dalam cerpen Jodoh digunakan tanpa afiks pada semua konteks. Hal ini dilakukan untuk memperoleh bentuk kebahasaan yang singkat, padat, dan ekonomis.

(1) Tak hirau pada ibunya yang begitu cemas memanggil-manggil (Navis, 1999: 4 )

(2) Aku tidak tahu, apakah dia tahu akalku, atau dia tidak hirau sama sekali...(Navis, 1999: 7)

Kata hirau dalam kalimat (1) dan (2) lazimnya dipakai dalam kalimat kalau sudah diberi imbuhan meng-kan menjadi menghiraukan. Penggunaan kata-kata tanpa afiks seperti itu dapat memberi efek tertentu bagi pembaca. Perhatikan penggunaan katakata tanpa afiks dalam kalimat berikut.

(3) ... aku remas pelan ujung bahunya. (Navis, 1999: 8)

(4) Maka aku geser tanganku lebih ke bawah.... (Navis, 1999: 9)

(5) Aku elus kulitnya yang halus (Navis, 1999: 9)

(6) Tak aku lupa segalanya. (Navis, 1999: 9)

(7) Aku tekan pedal rem dan setelah sedan berhenti aku peluk seluruh tubuhnya. (Navis, 1999: 9)

(8) Aku tancap gas sehingga sedan itu seperti mau melompat. (Navis, 1999: 9)

(9) Dia buka pintu sedan. (Navis, 1999: 10)

(10)... lalu aku rangkul pada bahunya. (Navis, 1999: 12) 
(11) Aku cium rambutnya. (Navis, 1999: 12)

(12) Aku lihat dayang belum masuk ke rumah. (Navis, 1999: 10)

Dalam kalimat (3) sampai (12) terdapat kata-kata yang digunakan tanpa afiks. Jika diberi afiks, kata-kata tersebut masing-masing menjadi meremas, menggeser (-kan), mengelus, melupakan, menekan, memeluk, menancap, membuka, merangkul, mencium, dan melihat.

\section{b. Penyederhanaan Afiks meng-i menjadi $D-i$}

Kata-kata yang berafiks meng- $i$ termasuk verba transitif, yaitu verba yang diikuti langsung oleh objek. Dalam cerpen Jodoh, verba transitif yang berafiks meng- $i$ penggunaannya disederhanakan konstruksinya dengan melesapkan prefiks meng- sehingga menjadi dasar + sufiks $-i$ (D-i).

(13) Di rumah itu aku dapati seorang anak muda.... (Navis, 1999: 74)

(14) Hati-hati aku ikuti mereka. (Navis, 1999: 16)

(15) Aku tanyai betul maunya Marabusu. (Navis, 1999: 33)

(16) Aku kuliti dia. (Navis, 1999: 64)

Data (13) sampai (16) terlihat penggunaan kata kerja berakhiran $-i$, tetapi tidak menggunakan prefiks meng-. Dalam kalimat (13) kata dapati dapat dibentuk menjadi mendapati. Demikian juga kata ikuti, tanyai, dan kuliti pada kalimat (14), (15), dan (16) dapat dibentuk menjadi mengikuti, menanyai, dan menguliti.

\section{c. Penyederhanan Afiks meng-kan menjadi D-kan}

Navis juga gemar menggunakan kata bentukan dengan sufiks -kan tanpa prefiks meng-.

(17) Papa sudah ceraikan mamamu. (Navis, 1999: 25)

(18) Atau aku batalkan saja ke rumahnya? (Navis, 1999: 36)
(19) Aku jatuhkan tanganku ke bahunya. (Navis, 1999: 8)

(20) Aku lepaskan tangan kiriku dari setir. (Navis, 1999: 12)

Dalam kalimat (17) sampai (20) terlihat kata-kata yang berakhiran -kan, tanpa prefiks meng-. Dalam bahasa formal, prefiks mengdalam kata-kata tersebut seharusnya dipakai sehingga kata-kata dalam kalimat di atas masingmasing menjadi; menceraikan, membatalkan, menjatuhkan, dan melepaskan. Membaca Jodoh karya Navis dengan kata-kata tanpa afiks mengseperti itu terasa lebih akrab karena sepertinya dilibatkan dalam situasi santai. Di samping itu, hal tersebut dapat memberi efek estetis. Navis menggunakan corak bahasa lisan.

\section{Pelesapan Prefiks ber-}

Dalam cerpen Jodoh ditemukan pula kata-kata yang digunakan dengan melesapkan prefiks ber-. Beberapa contoh dapat kita lihat berikut ini.

(21) Lalu aku lari ke Rengat. (Navis, 1999: 33)

(22) Akhirnya aku pikir, aku yang telah keliru bertindak. (Navis, 1999: 62)

(23) Aku tanya pada adik,... (Navis, 1999: 90)

(24) Aku tidak bicara apa-apa. (Navis, 1999: 90)

Dalam kalimat (21) sampai (24) didapati penggunaan kata-kata tanpa afiks ber-. Pelesapan afiks ber- dilakukan untuk memperoleh kepadatan penggunaan unsur bahasa. Dalam bahasa tulis formal kata-kata tersebut seharusnya dibubuhi awalan ber- menjadi berlari, berpikir, bertanya, dan berbicara.

\section{Pelesapan Unsur Bentuk Ulang}

Bentuk ulang biasanya terdiri atas dua morfem, yaitu morfem dasar dan morfem ulang. Dalam cerpen-cerpen Navis, bentuk ulang itu digunakan dengan sengaja melesapkan morfem ulangnya. Hal ini dilakukan untuk mendapatkan bentuk kata yang lebih ekonomis (singkat dan 
padat). Ada tiga bentuk kata yang ditemukan dalam cerpen Jodoh yang berkaitan dengan pelesapan morfem ulang tersebut. Ketiga bentuk kata tersebut adalah seolah, berangsur, dan berpura.

(25) Seolah perawan tua merupakan cacat hidup. (Navis, 1999: 1)

(26) Secara berangsur aku tahu juga apa kesibukan .... (Navis, 1999: 73)

(27) Kau jangan berpura marah. (Navis, 1999: 33)

Kata seolah, berangsur, dan berpura di atas merupakan bentuk sederhana dari bentuk ulang seolah-olah, berangsur-angsur, dan berpura-pura.

\section{Pemanfaatan Afiks se-}

Afiks se- dapat memanfaatkan untuk membentuk kata. Dalam cerpen Jodoh, ternyata prefiks se- dimanfaatkan untuk membentuk kata-kata yang khas, di samping yang lazim baik bentuk maupun maknanya. Keanekaragaman bentuk dan makna kata yang dibentuk dengan prefiks se-tersebut dapat dilihat pada contoh berikut ini.

(28) Biasanya kawan-kawan seperkumpulan.... (Navis, 1999: 89)

(29) Kita tidak seJodoh lagi. (Navis, 1999: 28)

(30) ... agar kami tetap hidup sekumpul. (Navis, 1999: 79)

(31) ... sekeluar kamar ibu. (Navis, 1999: 83)

(32) Aku menyandarkan tubuhku selelahnya pada jok belakang. (Navis, 1999: 10)

Dalam kalimat (28) sampai (32) terdapat kata-kata yang dibentuk dengan prefiks se-. Prefiks ini juga dapat melekat pada nomina dasar, seperti perkumpulan dan jodoh. Kata seperkumpulan (28) bermakna satu/sama perkumpulan, dan kata sejodoh bermakna satu jodoh. Penggunaan kata bentukan dengan prefiks se-secara khas dan unik terlihat pada kata sekumpul. Penggunaan prefiks se- pada kata sekumpul kalimat (30) dapat digunakan prefiks ber- menjadi berkumpul. Penggunaan frasa hidup sekumpul dalam kalimat (30) itu sama maknanya dengan hidup berkumpul. Hal yang sama juga terlihat pada pembentukan kata sekeluar (31). Kata sekeluar itu dibentuk dengan prefiks se- + keluar (verba dasar). Kata sekeluar tersebut bermakna 'sesudah' atau 'sesudah keluar'.

\section{Pemanfaatan Afiks meng-i (-kan)}

Kata-kata dengan afiks meng- $i$ atau mengkan termasuk verba transitif. Verba jenis ini diikuti langsung oleh objek. Penggunaan katakata berafiks meng- $i$ dapat dilihat pada kalimatkalimat di bawah ini.

(33) Akulah yang disuruh Pak Kasi menyupiri sedan Playmouth miliknya. (Navis, 1999: 7)

(34) Duduk mematuti perempuanperempuan memasang pelaminan di ruang tengah. (Navis, 1999: 42)

(35) Ibu tiada mengeluh sedikit pun jika kelaparan merangkaki hidup kami. (Navis, 1999: 79)

(36) Selama ibu menawakali kepahitan hidupnya. (Navis, 1999: 79)

Dalam kalimat (33) sampai (36) terdapat kata-kata yang dibentuk dengan afiks meng-i, yaitu kata menyupiri dari bentuk dasar supir, mematuti dari bentuk dasar patut, merangkaki dari bentuk dasar rangkak, dan kata menawakali dari bentuk dasar tawakal.

Pembentukan kata dengan afiks meng-i pada kata-kata di atas mempunyai makna yang berbeda-beda. Kata menyupiri dalam kalimat (33) bermakna 'berlaku seperti supir'. Kata mematuti dalam kalimat (34) mengandung makna 'bersikap (patut) terhadap' perempuan. Kata merangkaki dalam kalimat (35) mengandung makna 'melakukan perbuatan (merangkak) di (objek)'. Kata menawakali dalam kalimat (36) juga bermakna 'bersikap (tawakal) terhadap'. 
Penggunaan kata-kata seperti di atas sangat khas dalam cerpen Jodoh karya A. A. Navis. Kata-kata yang dibentuk dengan kombinasi afiks meng- $i$ seperti tersebut di atas dapat memberikan efek estetis bagi cerpen Navis.

Selain penggunaan kata bentukan dengan meng-i, terdapat pula penggunaan kata bentukan dengan afiks meng-kan. Pembentukan kata dengan afiks meng-kan tersebut juga terasa khas. Perhatikan contoh berikut ini.

(37) Dan ibu telah empat bulan di rumah sakit, yang bukan saja memarahkan sakit badan ibu, juga menyakitkan hatinya.... (Navis, 1999: 94)

Kata memarahkan (37) dibentuk dari bentuk dasar parah dengan afiks meng-kan sehingga bermakna 'membuat sakit jadi parah'.

\section{Pemanfaatan Afiks di-i, dan ter-}

Afiks di-i dapat dimanfaatkan dengan baik oleh Navis untuk membentuk kata-kata dalam cerpennya. Kata-kata yang dibentuknya dengan sufiks $d i-i$ kelihatannya sangat khas. Hal itu terlihat pada penggunaan kata-kata dengan afiks $d i-i$ pada kalimat-kalimat di bawah ini.

(38) Apapun yang dimaui ayah, aku terima. (Navis, 1999: 50)

(39) Memaki dirinya sendiri yang bodoh, yang mau saja dikibuli. (Navis, 1999: 43)

Kata dimaui dalam kalimat (38) bersionim dengan kata diingini, atau disukai (ayah). Kata dikibuli merupakan pengaruh bahasa Jawa. Dalam pembentukan dan pemanfaatan kata, Navis betul-betul mampu mendayagunakan afiks-afiks yang ada untuk membentuk katakata yang khas. Perhatikan contoh berikut ini.

(40) Tapi Mak Adangmu akan ke Mekkah tahun ini, maka perhitungan terpaksa disegerakan. (Navis, 1999: 42)

Kata disegerakan dibentuk dari adverbia dasar segera dengan afiks di-kan. Pembentukan kata dari dasar segera dengan afiks tersebut tidak lazim digunakan. Karena itu pembentukan kata disegerakan itu termasuk khas A. A. Navis.

Selain kata bentukan dengan afiks $d i-i$ dan di-kan, terdapat juga kata-kata yang dibentuk dengan afiks ter-. Penggunaan afiks ter- dalam cerpen Jodoh karya A. A. Navis dapat dilihat dalam kalimat berikut ini.

(41) Ia ingin melakukannya berulang kali sampai hatinya terpuaskan. (Navis, 1999: 40)

(42) ... sehingga orang-orang pada terbingung-bingung memandangi peristiwa itu. (Navis, 1999: 40)

Bentuk kata seperti terpuaskan dalam kalimat (41) dan terbingung-bingung (42) termasuk bentukan yang sudah lazim digunakan dalam bahasa sehari-hari. Kekhasan kata-kata tersebut bukan saja bentuknya, melainkan juga memiliki kekhasan nuansa makna. Hal itu merupakan hasil kreativitas pengarang. Dalam hal ini, pengarang memiliki kebebasan untuk membentuk kata dengan memanfaatkan afiks-afiks tertentu untuk dilekatkan pada dasar-dasar tertentu sehingga terbentuklah kata yang memiliki kekhasan, baik bentuk maupun maknanya.

\section{Pelesapan Sufiks -an}

Dalam bahasa Indonesia, kata-kata bermakna resiprokal biasanya menggunakan afiks ber-an. Dalam cerpen Jodoh karya A. A. Navis, kata-kata seperti itu digunakan dengan membubuhi prefiks ber- saja, tetapi tidak diikuti sufiks -an. Perhatikan contoh dalam kalimat berikut ini.

(43) Mereka bergumul lagi. (Navis, 1999: 35)

(44) Sampai mereka bergumul. (Navis, 1999: 34)

(45) Aku tak akan berbantah dengan kau dalam soal ini. (Navis, 1999: 44)

Kata yang dibentuk dari dasar verba dengan prefiks ber-pada umumnya menyatakan makna' sedang mengerjakan'. Berdasarkan konteks kalimatnya, penggunaan kata berprefiks pada kata bergumul dan berbantah, 
tidak bermakna 'sedang mengerjakan', tetapi bermakna 'saling', yaitu 'saling bergumul' dan 'saling berbantah'.

\section{Bentuk Dasar Bahasa Minangkabau}

Bentuk morfologis yang digunakan Navis dalam cerpen Jodoh memiliki kekhasan atau keunikan. Hal ini terlihat pada penggunaan kata-kata bentukan yang masih asing bagi pembacanya, atau kata-kata bentukan yang kurang dikenal oleh masyarakat luas. Navis banyak menggunakan kata yang dibentuk dari bahasa Minangkabau. Afiks bahasa Indonesia yang digabung dengan bentuk dasar bahasa Minangkabau. Kata-kata tersebut menjadi sebuah bentukan kata yang khusus. Hal ini dapat dilihat pada kutipan berikut ini.

(46) Kulihat si gadis manis telah membelok ke kanan, ke jalan kecil yang berbencah di genang air. (Navis, 1999: 16)

(47) ... di zaman Cindur Mato dulu, tempat itu pesawangan benar-benar. (Navis, 1999: 16)

(48) Budi mereka manis, dan aku telah terlalu sering makan minum di rumah mereka, omong-omong seperti orang yang berdunsanak dekat. (Navis, 1999: 33)

(49) Dan kini terpasah ke air anyir. (Navis, 1999: 29)

(50) Ia tidak mau terpica lagi seperti dulu. (Navis, 1999: 41)

Dalam kalimat (33) sampai (37) terdapat kata-kata bentukan dari dasar bahasa Minangkabau dengan afiks bahasa Indonesia. Kata tersebut adalah berbencah, pesawangan, berdunsanak, terpasah, terpica, menyuruk, menghampaikannya, dan mendudu.

Kata berbencah (BM) dalam kalimat (33) dibentuk dari dasar bencah (BM) 'becek' dengan afiks ber, lalu menjadi berbencah' berlumpur/becek. Kata pesawangan (BM) dibentuk dari dasar sawang dengan afiks pean. Kata sawang bermakna 'tempat yang tidak didiami', sedangkan pesawangan bermakna 'tempat yang sunyi di antara dusun-dusun; tanah yang luas yang tidak didiami orang'. Kata berdunsanak dibentuk dari dasar dunsanak (BM) 'sanak saudara' dengan afiks ber-. Makna kata berdunsanak itu adalah 'mempunyai sanak keluarga/saudara'. Kata terpasah (BM) dibentuk dari pasah yang bermakna jatuh/ sampai ke (suatu tempat)'. Dalam kalimat (37) ada kata terpica (BM) yang bentuk dengan afiks ter- dari dasar pica' lengah/lalai/.

\section{PENUTUP}

Berdasarkan uraian pada pembahasan dan pengamatan yang dilakukan terhadap cerpen Jodoh karya A. A. Navis, ditemukan beberapa kekhasan pemanfaatan bentuk kata yaitu: (a) pelesapan prefiks meng. Pelesapan prefiks meng- pada kata tertentu ditemukan tiga bentuk, yaitu pelesapan prefiks meng-dari bentuk dasar, penyederhanaan afiks meng- $i$ menjadi $D$ - $i$, dan penyederhanaan afiks mengkan menjadi D-kan; (b) pelesapan prefiks ber-; (c) pelesapan unsur bentuk ulang; (d) pemanfaatan afiks se-; (e) pemanfaatan afiks meng-i (-kan); (f) pemanfaatan afiks $d i-i$ dan ter-; (g) pelesapan sufiks - an; (h) bentuk dasar bahasa Minangkabau. Penggunaan bentuk kata dengan kekhasannya masing-masing dilakukan untuk mencapai efek estetis. Pembentukan kata dengan bentuk dasar bahasa Minangkabau, selain dilakukan untuk kepentingan citraan lokal juga untuk memperkaya kosakata bahasa Indonesia.

\section{DAFTAR PUSTAKA}

A. Zaidan. (1994), Kamus Istilah Sastra. Jakarta: Balai Pustaka.

Al-Ma'ruf, \& Imron, A. (2012), Stilistika (Teori, Metode, dan Aplikasi Pengkajian Estetika Bahasa). Surakarta: Cakra Books.

Aminuddin. (1997), Stilistika: Pengantar Memahami Bahasa dalam Karya Sastra. Semarang: Ikip Semarang Press.

Badudu, J.S. (1982), Sari Kesusastraan Indonesia. Bandung: C.V. Pustaka Prima. 
Endraswara, S. (2011), Metodologi Penelitian Sastra: Epistimologi, Model, Teori, dan Aplikasi. Yogyakarta: CAPS.

Keraf, G. (1990), Diksi dan Gaya Bahasa. Jakarta: Gramedia.

Mustakim. (1994), Membina Kemampuan Berbahasa. Jakarta: Gramedia.

Navis, A.A (1999), Jodoh: Kumpulan Cerpen. Jakarta: Gramedia

Nurgiyantoro, B. (2014), Stilistika. Yogyakarta: Gadjah Mada University Press.

Semi, Atar (1993), Metode Penelitian Sastra. Bandung: Angkasa.

Sudjiman, Panuti (1993), Stilistika. Jakarta: Pustaka Utama Grafiti.

Ratna, N. K. (2016), Stilistika. Yogyakarta: Pustaka Pelajar.
Rene Wellek, A. W. (2013), Teori Kesusatraan. Jakarta: Gramedia.

Sayekti, D. (1995), Cerita Pendek Indonesia 1940--1960: Telaah Struktur. Jakarta: Pusat Pengembangan dan Pembinaan Bahasa.

Subroto, E. (1999), Ihwal Relasi Makna: Beberapa Kasus dalam Berbahasa Indonesia dalam Telaah Bahasa dan Sastra. Jakarta: Pusat Pengembangan dan Pembinaan Bahasa.

Verhaar, J. W. M. (1996), Asas-Asas Linguistik Umum. Yogyakarta: Gadjah Mada University Press. 